\title{
sciendo
}

\section{IMPACTS OF PREPUBERTAL REARING INTENSITY AND CALF HEALTH ON FIRST-LACTATION YIELD AND LIFETIME PERFORMANCE*}

\author{
Nina Volkmann ${ }^{1 \bullet}$, Nicole Kemper ${ }^{1}$, Anke Römer ${ }^{2}$ \\ ${ }^{1}$ Institute for Animal Hygiene, Animal Welfare and Animal Behaviour, University of Veterinary \\ Medicine Hannover, Foundation, Bischofsholer Damm 15, 30173 Hannover, Germany \\ ${ }^{2}$ Institute of Livestock Farming, Mecklenburg-Vorpommern Research Center for Agriculture \\ and Fisheries, Wilhelm-Stahl-Allee 2, 18196 Dummerstorf, Germany \\ •Corresponding author: nina.volkmann@tiho-hannover.de
}

\begin{abstract}
The objective of the present study was to investigate possible long-term effects of calf and heifer feeding intensity on first-lactation milk yield and lifetime efficiency (milk per day of life). Detailed records from a total number of 2,252 female German Holstein calves from one commercial farm were obtained from birth to culling. Data regarding all information about calf's birth, rearing time until first insemination, first calving, first-lactation yield and lifetime performance were collected over a 12-year period. This large data volume was merged, handled, checked for plausibility, classified and evaluated. Analyses revealed that body weight at an age of six months was significantly influenced by the average daily gain in the first two weeks of life $(\mathrm{P}<0.0001)$ and by the duration of treatment for respiratory diseases $(\mathrm{P}=\mathbf{0 . 0 0 8 0})$. Moreover, first-lactation yield was affected by average daily gain in the whole first year of life $(\mathrm{P}=0.0013)$ and particularly in the period of month nine to twelve $(\mathrm{P}=\mathbf{0 . 0 0 1 8 7})$. Lifetime efficiency was significantly influenced by body weight at first insemination $(\mathrm{P}=\mathbf{0 . 0 0 5 1})$, average milk yield $(\mathrm{P}<\mathbf{0 . 0 0 0 1})$ and reason for culling $(\mathrm{P}<0.0001)$. The results of this long-term study confirm that growth is important in general, but as shown by the negative correlation between average daily gain from month nine to twelve and the first lactation milk yield, nutrient intake (energy and protein) should be adapted to enable a controlled growth especially at certain periods of life. After six months of age, daily gain has to be controlled to avoid fat accumulation for a healthy and effective start of lactation. In addition, this analysis revealed that after passing first lactation, particularly health and fertility are the keys for a long efficient lifetime of dairy cows.
\end{abstract}

Key words: dairy cows, lifetime production, lifetime efficiency, longevity, long-term effects

Producing and rearing well developed calves and heifers is the key issue of an economical milk production with healthy, productive and long living cows. Several

\footnotetext{
*This study was funded by Sloten B.V.
} 
factors have to be taken into consideration to achieve this purpose. Previous studies primarily investigated the influence of individual stages of life on lactation performance, for example, effects of age at first calving (AFC) (Froidmont et al., 2013; Do et al., 2013; Krpálková et al., 2014) or the influence of rearing intensity (Zanton and Heinrichs, 2005; Macdonald et al., 2005; Müller et al., 2007; Moallem et al., 2010; Hultgren et al., 2011; Soberon and Van Amburgh, 2014). These studies led to feeding recommendations for rearing calves, or advices regarding an optimal AFC. On the contrary, there are hardly any studies considering the whole lifespan of the animals. For instance, Heinrichs and Heinrichs (2011) provided a comprehensive study demonstrating significant effects of dry matter intake at weaning, delivery score, body weight at first calving (BWC) and health of preweaning calves on the first-lactation production. They also reported that the delivery score had a negative impact on lifetime milk production. Moreover, Trilk and Münch (2010) revealed that daily gains during the first year and fertility of heifers and cows were lower with higher disease rate of young calves. Furthermore, based on their observations, they recommended that for optimal lifetime efficiency, the cows should reach an AFC of 24 to 27 months with a body weight of $600 \mathrm{~kg}$ after first calving (Trilk and Münch, 2010). The aim of the present study was to analyse possible long-term effects of rearing time on the later life of dairy cows until culling. For that purpose we investigated the effects of rearing intensity and calf diseases on performance in the first lactation, on longevity and lifetime production. Furthermore, focus was laid on identifying factors improving lifetime efficiency and performance to enhance animal welfare, and also farm economics.

\section{Material and methods}

\section{Animals and sample collection}

Data were collected from all female German Holstein calves born in the period 2000 to 2012 on a single commercial dairy farm with free-stall housing in Mecklenburg-Vorpommern, Germany. The milking herd on farm averaged about 450 Holstein cows and the own offspring of about 300 animals. Cows were milked three times a day and in 2012 the herd reached a mean performance of 10,602 $\mathrm{kg}$ milk per cow containing $4.07 \%$ fat and $3.39 \%$ protein.

For the present study, all stillborn or malformed calves were excluded from the data set, as well as all animals, which died within three days after birth or those intended for fattening or selling. This resulted in a total number of 2,252 female calves. At the calving the farmer/farm employee recorded calving difficulty using a delivery score with five levels as follows: $0=$ not observed; $1=$ without assistance; $2=$ slight assistance; $3=$ strong assistance; $4=$ caesarean/fetotomy (recommended by the German Cattle Breeders' Federation ADR, 2000). After calving, all calves were immediately removed from their dams, were weighed with a calf weigh scale (EziWeigh 2, Tru-Test Group, New Zealand) and subsequently fed 1.5-2.0 liters of colostrum. Calves were housed in individual outside hutches for at least two weeks which were 
equipped with buckets for water and hay. In the first three days of life calves were fed colostrum three times a day and after that they got milk replacer $(45 \%$ skimmed milk powder). After two weeks all male calves were sold and the females were grouped together in a calf igloo. After grouping calves got some farm-based concentrates additionally. Generally all calves were weaned after nine weeks of drinking period. During the time of weaning, each calf was weighed after two, six and nine weeks. Moreover, the farmer and the veterinarian collected the data on diarrhea and respiratory diseases in the first nine weeks of life, its duration and at least type of treatment. In this regard, in the present study only antibiotic treatment was documented. After weaning calves were fed some starter mix and some milking-cow ration to be gradually adjusted to a growing-heifer ration. For heifers there were different feeding rations in dependence on their age and status. Until the first insemination the rations were more intensive and corresponded to the feeding of medium to low yielding dairy cows of the herd. For pregnant heifers the ration had lower energy content and was mainly grass based. Likewise, the heifers were weighed with weighing system FX 41 (Texas Trading GmbH, Windach, Germany). We analysed weight at first breeding if date of weighing was \pm 45 days from date of first insemination. The animals are weighed every two months on the farm and with the used date line as few values as possible will be lost. The weights at first calving were included into calculation if date of weighing was \pm 10 days from date of calving. Additional performance of these animals such as parity, energy-corrected milk yield for 305 days in first lactation, overall milk production and longevity (time from first calving to culling, i.e. productive life) were obtained from the official milk recording program (by vit; according to ICAR-approved milk recording method) and were analysed until 31 May 2014. Further information included in the analysis was extracted from the herd management software (AGROCOM SUPERKUH, CLAAS Agrosystems, Germany) and is listed in Table 1. Due to the large data volume, the collected information from each animal had to be merged and to be checked with regard to plausibility. Therefore, data structures were prepared and merged using Microsoft Office Access 2002 (Microsoft Corporation, Unterschleißheim). Data handling included identification and deletion of duplicate records. Furthermore, processing such data contained categorizing and classifying explanatory variables.

Table 1. Traits analysed from 2,252 dairy cows from one herd from 2000-2012

\begin{tabular}{l|l}
\hline \multicolumn{1}{c|}{ Trait } & \multicolumn{1}{c}{ Description / Calculation } \\
\hline 1 & \\
\hline Calf's day of birth & Date; year; season \\
Parity of the dam & Parity \\
Code of multiple birth & Singleton or twin \\
Delivery score & $0=$ not observed; 1=without assistance; 2=slight assistance; \\
& $3=$ strong assistance; 4=caesarean/fetotomy \\
Body weight at birth & Calf's weight $(\mathrm{kg})$ at day of birth \\
\hline
\end{tabular}


Table 1 - contd.

\begin{tabular}{|c|c|}
\hline 1 & 2 \\
\hline Liveweight gain in rearing time & $\begin{array}{l}\text { Daily gain }(\mathrm{g}) \text { : } \\
\text { 1. Day } 0 \text { to day } 14 \\
\text { 2. Day } 0 \text { to day } 42 \\
\text { 3. Day } 0 \text { to day } 63 \\
\text { 4. Day } 63 \text { to third month } \\
\text { 5. Third to six months } \\
\text { 6. Six to nine months } \\
\text { 7. Nine to twelve months } \\
\text { 8. Day } 0 \text { to twelve months }\end{array}$ \\
\hline Diseases until weaning & Diarrhea and respiratory diseases \\
\hline Day of treatment & Duration of treatment because of diarrhea or respiratory diseases \\
\hline Antibiotic treatment & Antibiotic treatment because of diarrhea or respiratory diseases \\
\hline Age at first insemination & $\begin{array}{l}\text { Time between birth and first insemination in months (one month }= \\
30.5 \text { days) }\end{array}$ \\
\hline Weight at first insemination & Weight at first insemination $(\mathrm{kg})( \pm 45$ days $)$ \\
\hline Effort of insemination & Number of inseminations until first pregnancy \\
\hline Age at first calving & Months between birth and first calving (one month $=30.5$ days) \\
\hline Body weight after first calving & Body weight after first calving $(\mathrm{kg})( \pm 10$ days $)$ \\
\hline Liveweight gain until first calving & $\begin{array}{l}\text { Daily gain }(\mathrm{g}) \text { : } \\
\text { 1. Day } 0 \text { until first calving ( } \pm 10 \text { days }) \\
\text { 2. Twelve month until first calving }( \pm 10 \text { days })\end{array}$ \\
\hline First lactation yield & First 305-day ECM yield (kg) \\
\hline Lifetime production & Overall milk yield $(\mathrm{kg})$ \\
\hline Parities & Sum of parities \\
\hline Performance per lactation & Average 305 -day ECM milk yield per lactation $(\mathrm{kg})$ \\
\hline Reason for culling & $\begin{array}{l}1=\text { Selling for breeding, } 2=\text { Age, } 3=\text { Low performance, } 4=\text { Infertility, } \\
5=\text { Diseases not further defined, } 6=\text { Udder diseases, } 7=\text { Milkability, } \\
8=\text { Diseases of claws or limbs, } 9=\text { Other reasons, } 10=\text { Metabolic } \\
\text { disorders }\end{array}$ \\
\hline Longevity & Time from first calving to culling \\
\hline Lifetime efficiency & Milk yield $(\mathrm{kg})$ per living day \\
\hline
\end{tabular}

\section{Statistical analysis}

The data set was analysed according to the models described in equations 1-3, using the GLM procedure of SAS 9.2 (SAS Institute, 2008). The Tukey method was applied for the least square means. Differences between the estimated variables were tested on a level of significance of $\mathrm{P}<0.05$. A type of backward elimination was used, to find the best statistical model for each dependent variable, and to select all important effects. Best model fit was judged finally by goodness-of-fit. The model for rearing intensity represented by body weight at an age of six months was as follows: 


$$
y_{i j k l m \text { порq }}=Y_{i}+S_{j}+L M_{k}+D S_{l}+M B_{m}+R D_{n}+D D_{o}+B W_{p}+A D G 0_{-} 14_{q}+e_{i j k l m \text { порq }}[1]
$$

where:

$y_{i j k l m n o p q}$ is the body weight at an age of six months,

$Y_{i}$ the effect of year of birth $(i=2000, \ldots, 2012)$,

$S_{j}$ the effect of season of birth,

$L M_{k}$ the effect of mother's lifetime parity $(k=1, \ldots, 9)$,

$D S$ the effect of delivery score,

$M B_{m}$ the effect of multiple birth code ( $m=$ singleton or twin),

$R D_{n}$ the effect of number of days of veterinary treatments for respiratory diseases $(n=0, \ldots, 8)$,

$D D_{o}$ the effect of number of days of veterinary treatment for diarrhea $(o=0, \ldots, 7)$, $B W_{p}$ the effect of weight at birth,

$A D G 0_{-} 14_{q}$ the effect of average daily weight gain in the first two weeks of life, $e_{i j k l m n o p q}$ stands for the random error.

Equation 2 was used for determining the effect of selected factors on the dependent variable of 305-day ECM first lactation yield:

$y_{i j k l m n o p}=Y_{i}+S_{j}+L M_{k}+B W_{l}+183 D_{m}+A D G 0 \_365_{n}+A D G 274 \_365_{o}+A F C_{p}+e_{i j k l m n o p}[2]$

where:

$y_{i j k l m n o p}$ is the 305-days ECM first lactation yield,

$Y_{i}$ the effect of year at birth $(i=2000, \ldots, 2012)$,

$S_{j}$ the effect of season at birth,

$L M_{k}$ the effect of mother's lifetime parity,

$B W_{l}$ the effect of weight at birth,

$183 D_{m}$ the effect of weight after six months,

$A D G 0 \_365_{n}$ the effect of average daily weight gain in the first year of life,

$A D G 274 \_365_{o}$ the effect of average daily weight gain from month nine to twelve of life,

$A F C_{p}$ the effect of age at first calving,

$\mathrm{e}_{\mathrm{ijklmnop}}$ is the random error.

The model for lifetime performance was defined by Equation 3:

$$
y_{i j k l m n o}=Y_{i}+L M_{j}+R C_{k}+B W_{l}+A D G 274_{-} 365_{m}+W F I_{n}+A M Y_{o}+e_{i j k l m n o}[3]
$$

where:

$y_{i j k l m n o}$ is the lifetime performance,

$Y_{i}$ the effect of year at birth $(i=2000, \ldots, 2012)$,

$L M_{j}$ the effect of mother's lifetime parity $(j=1, \ldots, 9)$,

$R C_{k}$ the effect of reason for culling,

$B W_{l}$ the effect of weight at birth, 
ADG274_365 ${ }_{m}$ the effect of average daily weight gain from month nine to twelve of life,

$W F I_{n}$ the effect of weight at first insemination,

$A M Y_{o}$ the effect of average milk yield,

$\mathrm{e}_{\mathrm{ijklmno}}$ stands for the random error.

\section{Results}

\section{General observations}

Annually, an average number of 173 female calves were born ( $\min =126$; $\max =229)$ in the evaluated years. The majority of animals were singleton $(97 \%)$ and from heifers $(33 \%)$. The distribution to the delivery score was as follows: score $0=14$ calves $(0.7 \%)$; score $1=1,307$ calves $(58.0 \%)$; score $2=703$ calves $(31.2 \%)$; score $3=226$ calves $(10.0 \%)$ and score $4=2$ calves $(0.1 \%)$. The average birth weight was $41.4 \mathrm{~kg}(\mathrm{~min}=17.0 \mathrm{~kg}$; $\max =65.0 \mathrm{~kg}$ ) (Table 2). Results for average daily gain (ADG) and live weight for different periods of life are presented in Table 2. With regard to documented diseases, in the first 63 days of life (drinking period), diarrhea as well as respiratory diseases occurred in $9 \%$ and $5 \%$ of calves, respectively. The majority of these calves were treated by a veterinarian only once (diarrhea $=42 \%$; respiratory diseases $=47 \%$ ). Furthermore, from those calves, $29 \%$ with diarrhea and $69 \%$ with respiratory diseases were treated with antibiotics. At first insemination the animals showed an average weight of $435 \mathrm{~kg}(\min =262 \mathrm{~kg}$; $\max =652 \mathrm{~kg})$ at an average age of 15.5 months $(\min =11.4 ; \max =23.7)$ (Table 2$)$. Average weight at first calving was $613 \mathrm{~kg}(\min =461 \mathrm{~kg}$; $\max =936 \mathrm{~kg})$, with a pregnancy index (average number of inseminations per lactation until positive gestation diagnosis) of 1.7 $(\min =1 ; \max =8)$ and the AFC being 25.5 months ( $\min =21.1 ; \max =38.4$ ) (Table 2). A mean 305-day ECM first lactation yield of 9,566 kg was achieved by the animals on the farm studied $(\min =3,313 \mathrm{~kg} ; \max =15,291 \mathrm{~kg}$ ). The mean parity in the herd over the 12-year period was 2.8 (Table 2). Mean milk yield per lactation was 8,405 $\mathrm{kg}(\min =0 \mathrm{~kg} ; \max =23,711 \mathrm{~kg}$ ) and average lifetime production (total amount of milk yield) amounted to $26,251 \mathrm{~kg}$, where the lowest value was zero from young cows leaving the herd before finishing the first milk recording ( $\max =96,965 \mathrm{~kg}$ ). Mean lifetime efficiency (milk yield per day of living) was $12.9 \mathrm{~kg}$ ( $\mathrm{min}=0 \mathrm{~kg}$; $\max =29.0 \mathrm{~kg}$ ). Altogether, median longevity was 30.7 months; this value includes also animals leaving the herd one day after calving ( $\min =1$ day; $\max =113.7$ months) (Table 2). Over all cullings (culling was defined as the removal of animals from the herd), most important reasons for cullings were infertility (27\%), selling for breeding $(14 \%)$, diseases not further defined (13\%), diseases of claws and limbs $(12 \%)$ and metabolic disorders $(12 \%)(n=1.674)$. After first calving, a total number of 155 cows (14.6\%) delivered milk for only six months before being culled. Most of these animals in the first lactation were culled because of udder diseases (45\%), in the second lactation due to infertility (32\%), and, in the consecutive lactations, because of metabolic disorders $(27 \%)$. 
Table 2. Number of records $(\mathrm{N})$, mean and standard deviation (SD) for each of the performance variables analysed

\begin{tabular}{|c|c|c|c|}
\hline Trait & $\mathrm{N}$ & Mean & SD \\
\hline Birth weight $(\mathrm{kg})$ & 2.252 & 41.4 & 4.9 \\
\hline $\mathrm{ADG}^{1}$ day 0 to $14(\mathrm{~g})$ & 2.171 & 534 & 244 \\
\hline $\mathrm{ADG}^{1}$ day 0 to $42(\mathrm{~g})$ & 2.112 & 544 & 152 \\
\hline $\mathrm{ADG}^{1}$ day 0 to $63(\mathrm{~g})$ & 2.081 & 610 & 134 \\
\hline $\mathrm{ADG}^{1}$ day 63 to 3 months (g) & 2.058 & 985 & 209 \\
\hline $\mathrm{ADG}^{1} 3$ to 6 months (g) & 1.998 & 1,052 & 173 \\
\hline $\mathrm{ADG}^{1} 6$ to 9 months (g) & 1.952 & 930 & 263 \\
\hline $\mathrm{ADG}^{1} 9$ to 12 months (g) & 1.894 & 828 & 218 \\
\hline $\mathrm{ADG}^{1}$ day 0 to 12 months (g) & 1.894 & 887 & 94 \\
\hline Age at first insemination (months) & 1.842 & 15.5 & 1.66 \\
\hline Weight at first insemination $(\mathrm{kg})$ & 1.645 & 435 & 49.2 \\
\hline Pregnancy index & 1.622 & 1.7 & 1.1 \\
\hline Age at first calving (months) AFC & 1.634 & 25.5 & 2.29 \\
\hline $\mathrm{ADG}^{1}$ day 0 to day of first calving (g) & 435 & 740 & 103 \\
\hline $\mathrm{ADG}^{1} 12$ month to day of first calving $(\mathrm{g})$ & 435 & 617 & 183 \\
\hline First 305-day ECM yield (kg) & 928 & 9.566 & 1.529 \\
\hline Longevity (months) & 1.089 & 30.8 & 22.6 \\
\hline Average lifetime production $(\mathrm{kg})$ & 1.089 & 26.251 & 20.694 \\
\hline Parities & 1.089 & 2.8 & 1.6 \\
\hline Mean milk yield per lactation $(\mathrm{kg})$ & 1.089 & 8.404 & 4.415 \\
\hline Lifetime efficiency $(\mathrm{kg})$ & 1.089 & 12.9 & 7.1 \\
\hline
\end{tabular}

${ }^{1} \mathrm{ADG}=$ average daily gain.

\section{Analysis of influences on rearing intensity}

Body weight (BW) at an age of six months (defined as rearing intensity) was affected by the year and season of birth, birth weight and ADG in the first two weeks of life (all $\mathrm{P}<0.01$ ) shown in Table 3. Calves born in summer achieved significantly less weight after six months' rearing time than calves born in winter, spring or fall. Furthermore, mothers' parity $(\mathrm{P}=0.02)$ and the number of days of veterinary treatment for respiratory diseases $(\mathrm{P}=0.01)$ influenced the rearing intensity. Calves treated for a maximum of one day achieved significantly higher BW after six months than animals requiring veterinary treatment for four days $(203.1 / 204.2 \mathrm{~kg}$ vs. $181.8 \mathrm{~kg})$. Until the fifth day of veterinary treatment, BW showed a decreasing tendency.

\section{Analysis of influences on first lactation milk yield}

First lactation milk yield (FLY) was affected by the year and season of birth, the parity of the mother, the ADG in the first twelve months (all $\mathrm{P}<0.01$ ) as well as by the ADG in months 9 to $12(\mathrm{P}=0.01)$, and by AFC $(\mathrm{P}<0.01)$. Cows with ADG of $925-1,000 \mathrm{~g} / \mathrm{d}$ in the first year had significantly lower FLY $(9,125 \mathrm{~kg})$ than those 
with more than $1,000 \mathrm{~g} / \mathrm{d}$ ADG $(9,706 \mathrm{~kg})$ (Table 4). Furthermore, animals with an $\mathrm{ADG}$ in the period from month nine to twelve with more than $1,100 \mathrm{~g} / \mathrm{d}$ achieved $340 \mathrm{~kg}$ less FLY than those with a moderate growth rate of $775-900 \mathrm{~g} / \mathrm{d}(8,973 \mathrm{~kg} \mathrm{vs}$. $9,314 \mathrm{~kg})$.

Table 3. Influences of season of birth, days of veterinary treatments for respiratory diseases, average daily gain in the first two weeks of life (ADG0_14) and mothers parity on rearing intensity after six months

\begin{tabular}{|c|c|c|}
\hline Trait & $\mathrm{N}$ & Weight after six months ${ }^{\mathrm{A}}$ \\
\hline \multicolumn{3}{|l|}{ Season of birth } \\
\hline spring & 570 & $200 \mathrm{a}$ \\
\hline summer & 542 & $193 \mathrm{~b}$ \\
\hline fall & 616 & $200 \mathrm{a}$ \\
\hline winter & 524 & $201 \mathrm{a}$ \\
\hline \multicolumn{3}{|c|}{ Number of days of veterinary treatment for respiratory diseases } \\
\hline 0 & 2,131 & $203 \mathrm{a}$ \\
\hline 1 & 57 & $204 \mathrm{a}$ \\
\hline 2 & 15 & $199 \mathrm{ab}$ \\
\hline 3 & 9 & $198 \mathrm{ab}$ \\
\hline 4 & 10 & $182 \mathrm{~b}$ \\
\hline 5 & 8 & $185 \mathrm{ab}$ \\
\hline 6 & 2 & $199 \mathrm{ab}$ \\
\hline 7 & 2 & $203 a b$ \\
\hline 8 & 18 & $211 \mathrm{ab}$ \\
\hline \multicolumn{3}{|l|}{ ADG0_14 (g/d) } \\
\hline$<100$ & 93 & $183 \mathrm{a}$ \\
\hline$\geq 100 x<300$ & 225 & $188 \mathrm{ab}$ \\
\hline$\geq 300 x<400$ & 242 & $193 \mathrm{bc}$ \\
\hline$\geq 400 x<500$ & 312 & $195 \mathrm{~cd}$ \\
\hline$\geq 500 x<600$ & 431 & $198 \mathrm{de}$ \\
\hline$\geq 600 x<700$ & 399 & 203 ef \\
\hline$\geq 700 x<800$ & 219 & $207 \mathrm{f}$ \\
\hline$\geq 800 \mathrm{x}<1.000$ & 183 & $208 \mathrm{f}$ \\
\hline$\geq 1.000$ & 67 & $208 \mathrm{f}$ \\
\hline \multicolumn{3}{|l|}{ Mothers parity } \\
\hline 1 & 746 & $195 \mathrm{a}$ \\
\hline 2 & 592 & $197 \mathrm{ab}$ \\
\hline 3 & 371 & $200 \mathrm{~b}$ \\
\hline 4 & 267 & $199 \mathrm{ab}$ \\
\hline 5 & 126 & $199 \mathrm{ab}$ \\
\hline 6 & 64 & $198 \mathrm{ab}$ \\
\hline 7 & 51 & $196 a b$ \\
\hline 8 & 24 & $202 \mathrm{ab}$ \\
\hline 9 & 11 & $195 \mathrm{ab}$ \\
\hline
\end{tabular}

$\mathrm{a}, \mathrm{b}-$ columns with different letters differ significantly $(\mathrm{P}<0.05)$.

${ }^{\mathrm{A}}$ LSMeans. 
Table 4. Influences of average daily weight gain in the first year of life (ADG0_365) and during months nine to twelve (ADG 274_365) on first lactation milk yield (FLY)

\begin{tabular}{|c|c|c|}
\hline Item & $\mathrm{N}$ & FLY $(\mathrm{kg})^{\mathrm{A}}$ \\
\hline \multicolumn{3}{|l|}{ ADG $0 \_365(\mathrm{~g} / \mathrm{d})$} \\
\hline$<800$ & 297 & $8.966 \mathrm{ab}$ \\
\hline$\geq 800 x<870$ & 468 & $9.158 \mathrm{ab}$ \\
\hline$\geq 870 x<925$ & 487 & $9.348 \mathrm{ab}$ \\
\hline$\geq 925 \mathrm{x}<1,000$ & 451 & $9.152 \mathrm{a}$ \\
\hline$\geq 1,000$ & 191 & $9.706 \mathrm{~b}$ \\
\hline \multicolumn{3}{|l|}{ ADG 274_365 (g/d) } \\
\hline$<625$ & 273 & 9.320 \\
\hline$\geq 625 x<775$ & 458 & 9.396 \\
\hline$\geq 775 x<900$ & 508 & 9.314 \\
\hline$\geq 900 \mathrm{x}<1,100$ & 475 & 9.324 \\
\hline$\geq 1,100$ & 180 & 8.973 \\
\hline
\end{tabular}

$\mathrm{a}, \mathrm{b}-$ columns with different letters differ significantly $(\mathrm{P}<0.05)$.

${ }^{\text {A }}$ LSMeans.

\section{Analysis of influences on lifetime efficiency}

Lifetime efficiency, defined as milk yield per living day, was affected by year of birth, reason for culling, average milk yield and weight at first insemination (all $\mathrm{P}<0.01$ ). Reason for culling was only taken into account in the case of cows, which had previously not been sold as breeding animals. Thus, the reason for culling can also be interpreted as diseases suffered, leading to the exclusion of the animal from the productive herd. Lowest lifetime efficiency was performed by cows culled for infertility reasons (Table 5). Therefore, infertility is not only the most frequent reason for culling, but also a reproductive risk factor for culling. Lifetime efficiency decreased with an increasing weight at first insemination. With regard to first insemination, mean values between lightest animals with $<385 \mathrm{~kg}$ and heaviest with $\geq 480$ $\mathrm{kg}$ at first insemination differed by 1.6 kilograms of milk per day (Table 5).

Table 5. Influences of reasons for culling, weight at first insemination and average milk yield on lifetime efficiency

\begin{tabular}{l|c|c}
\hline \multicolumn{1}{c|}{ Item } & $\mathrm{N}$ & Lifetime efficiency $(\mathrm{kg} / \mathrm{d})^{\mathrm{A}}$ \\
\hline \multicolumn{1}{c|}{1} & 2 & 3 \\
\hline Reason for culling & 53 & \\
$\quad$ low milk yield & 459 & $13.5 \mathrm{a}$ \\
infertility & 223 & $10.9 \mathrm{~b}$ \\
other diseases & 159 & $13.8 \mathrm{a}$ \\
udder diseases & 8 & $14.0 \mathrm{a}$ \\
milkability & 205 & $14.3 \mathrm{ab}$ \\
diseases of claws and limbs & 96 & $13.3 \mathrm{a}$ \\
other reasons & 201 & $12.7 \mathrm{ab}$ \\
metabolic disorders & & $14.5 \mathrm{a}$ \\
\hline
\end{tabular}


Table 5 - contd.

\begin{tabular}{|c|c|c|}
\hline 1 & 2 & 3 \\
\hline \multicolumn{3}{|c|}{ Weight at first insemination $(\mathrm{kg})$} \\
\hline$<385$ & 224 & $14.1 \mathrm{a}$ \\
\hline$\geq 385 x<415$ & 376 & $13.6 \mathrm{a}$ \\
\hline$\geq 415 \mathrm{x}<445$ & 393 & $13.4 \mathrm{ab}$ \\
\hline$\geq 445 x<480$ & 375 & $13.3 \mathrm{ab}$ \\
\hline$\geq 480$ & 277 & $12.5 \mathrm{~b}$ \\
\hline \multicolumn{3}{|l|}{ Average milk yield $(\mathrm{kg})$} \\
\hline$<5,000$ & 223 & $2.2 \mathrm{a}$ \\
\hline$\geq 5,000 \mathrm{x}<8,000$ & 208 & $11.0 \mathrm{~b}$ \\
\hline$\geq 8,000 \mathrm{x}<10,000$ & 238 & $15.4 \mathrm{c}$ \\
\hline$\geq 10,000 \mathrm{x}<12,000$ & 223 & $18.2 \mathrm{~d}$ \\
\hline$\geq 12,000$ & 197 & $20.2 \mathrm{~d}$ \\
\hline
\end{tabular}

a, $\mathrm{b}$ - columns with different letters differ significantly $(\mathrm{P}<0.05)$.

A LSMeans.

\section{Discussion}

In the present study, calves were fed the generally recommended 6-8 1/day of milk replacer (Sherwin et al., 2016) and thus they achieved an ADG of $610 \mathrm{~g} / \mathrm{d}$. However, the calves did not reach an ADG of 620-650 g/d in the first 63 days recommended by DLG (2008) and certainly not the recently preferred target of a daily liveweight gain of 700-800 g/d (Krpálková et al., 2014). Therefore, we assumed they were fed too restrictively in the first time of rearing. In particular, calves with heavier birth weights are predestined to achieve higher body weight probably due to genetic disposition, but maybe also because larger calves competed more effectively for food (Bazeley et al., 2016). However, after six months the animals showed, with $890 \mathrm{~g} / \mathrm{d}$, growth rates slightly above the recommended 800-850 g/d (DLG, 2008). Thus, if the time until weaning was referred as (too) restrictively with reduced feed intake, the time after weaning would demonstrate the mechanism of compensatory growth. Hornick et al. (2000) described compensatory growth as "a physiological process whereby an organism accelerates its growth after a period of restricted development". The result is that the calves can reach same body weight like those whose growth was never reduced. However, such compensatory growth is not recommended because gastrointestinal development and metabolic health is declined by malnutrition in early life (He et al., 2009). The rearing intensity was affected by year and season of birth and calves born in summer achieved lower BW at an age of six month than calves born in spring, fall or winter. One reason for this reduced growth might be heat stress of the mother cow, as high temperatures can lead to reduced placental blood flow and oxygen supply of fetus (De Rensis and Scaramuzzi, 2003; West, 2003). Moreover, due to a minor quality of colostrum, the amount of transferred maternal immunoglobulins can be reduced, when cows suffered heat stress in the 
last three weeks of gestation (Nardone et al., 1997). Furthermore, high temperatures can limit the calf's absorption of immunoglobulins (Stott, 1980; Rutherford, 2014). These aspects can cause negative effects on calves' growth and health. In the present study calves with lower birth weight maintained their reduced weight even after six months of rearing time. Particularly ADG in the first two weeks of life showed a strong effect on the rearing performance, thus, body weight at the end of weaning. Calves with ADG less than $100 \mathrm{~g} / \mathrm{d}$ showed statistically significant mean differences in BW compared to calves with ADG $>1,000 \mathrm{~g} / \mathrm{d}(183 \mathrm{~kg}$ vs. $208 \mathrm{~kg})$. Similar results were found also in another study on female calves (Wiedemann et al., 2015), but as well in bull calves (Maccari et al., 2015). Also respiratory diseases negatively influenced the weight gain of the calves over the rearing period. Trilk and Münch (2010) also confirmed negative effects of diseases on ADG during the first year. They found that lower growth in several diseased calves was not compensated during the rearing period. The same tendency (approximately $-50 \mathrm{~g} / \mathrm{d}$ on preweaning ADG) was observed in the study by Soberon et al. (2012) in calves which showed diarrhea and furthermore were treated with antibiotics because of respiratory diseases.

In the present study, the season of birth affected the FLY. Cows born in spring showed significantly lower FLY $(8,921 \mathrm{~kg})$ compared to animals born in fall $(9,441 \mathrm{~kg})$ or winter $(9,468 \mathrm{~kg})$. Influences of environmental temperatures at birth on the later performance were also described by Soberon et al. (2012), showing reduced milk yields - primarily in heifers suffering from cold stress at birth. However, these findings were not confirmed in the present study. Our observations support a negative effect of high temperatures at birth on ADG and weight after six months as described above. Furthermore, cows born in spring calve usually in summer for the first time, and the season of birth does not only show a negative effect on FLY, but also on general performance, as shown by Monteiro et al. (2016). Also the ADG in the first twelve months as well as from month 9 to 12 had influences on FLY. Because of our result, we would suggest an average ADG about 870-925 g/d in the first twelve months for a high FLY (Table 4). As can be seen, calves which grow more than $1,000 \mathrm{~g} / \mathrm{d}$ could achieve even more FLY. But, due to the lower number of animals and the greater risk to body fatness (Le Cozler et al., 2008), this result could not affect our recommendation at all. Other studies concluded an optimum ADG of about 700 g/d (Shamay et al., 2005) or rather 900 g/d (Mourits et al., 2000; Vacek et al., 2015) for achieving maximal performance. Overall, an increased growth rate showed positive effects on FLY. On the other hand, prepubertal intensive rearing was interpreted as compensatory growth and this has negative effects on body composition, performance, metabolism and endocrine status (Hornick et al., 2000; Meyer et al., $2006 \mathrm{a}, \mathrm{b})$. In our study, this effect is obvious in the impact of ADG from month nine to twelve on FLY. When animals achieve compensatory growth, fat deposition takes over and the cows are getting fatter (Hornick et al., 2000). Furthermore, if increased body fatness entails increased growth rate before puberty onset can lead to reduced mammary development and therefore reduced milk production (Sejrsen et al., 2000). Krpálková et al. (2014) described the highest FLY in groups of animals which reached up to $969 \mathrm{~g} / \mathrm{d}$ in the prepubertal growth period. Zanton and Heinrichs (2005) documented an increased first-lactation production at ADG of $836 \mathrm{~g} / \mathrm{d}$. In 
the present study, animals with the highest growth rate during month nine to twelve achieved $340 \mathrm{~kg}$ less FLY than those with a moderate growth rate. Further aspects with body fatness are problems at calving. Animals with increased body condition tend to have bigger and heavier calves - and this can result in dystocia with subsequent inflammation of uterus or placental retention (DLG, 2008). In addition, the body of those fatty cows after calving responds with a massive decomposition of body fat. This can lead to a pronounced and pathogenic lack of energy (ketosis) (Spiekers and Potthast, 2004). Intensive rearing of heifers, as assessed by increase of liveweight gain, resulted in early puberty, allowed for an early insemination and aimed to generate a high first lactation milk yield (Huber, 2018). But, the process of maturity and rearing needs time - and compensatory growth could not be recommended as healthy growth.

The weight gain also had an effect on lifetime efficiency (milk yield per living day) - with an increasing weight at first insemination lifetime efficiency decreased. According to Leonard et al. (2013), weight at first insemination should be within a range of 380-420 kg (at an age of 14-15 months). In our study, this recommendation corresponds to the results for animals with weights up to $415 \mathrm{~kg}$ at first insemination. These animals also achieved highest lifetime efficiency. Moreover, lifetime efficiency also increased significantly with increasing average milk yield. These effects of average lactation performance reflected the milk yield potential which had been bred to modern dairy cows. VandeHaar et al. (2016) even concluded that in high-yielding cows a dilution of maintenance in favour of a greater proportion of energy toward milk production can be effected be genetic selection. Therefore, they are genetically influenced to a large extent, but also depending on the culling management on farms, with keeping cows longer depending on their average performance and health.

In conclusion, we recommend an accurate and permanent documentation on farm. The recording of calf's birth weight is the basis of the measurement and monitoring of its growth and development. Further weighing will be very useful at weaning, at puberty and at first insemination. Additional documentation should include health data for an easier and earlier detection of stock problems, to optimize herd health and support selection decisions. In general, we would like to advise that calves and heifers, which should have a healthy, long and productive life span, need time for maturation and ontogenic growth.

\section{Acknowledgements}

We thank the participating farm staff for the support, and Jana Flor and Bernd Losand for their help in on-farm recordings and data editing. The study was funded by Sloten B.V.

\section{References}

ADR (2000). ADR-Recommendation 3.1 - Performance test for functional traits of bulls and cows (health, reproduction, lifetime, exterior, milkability). Accessed Apr. 11, 2017 www.adr-web.de/services/files/.../20160412\%20ADR-Empfehlung\%203.1.pdf 
B a z e le y K.J., B a r re t t D.C., Wi 11 i a m s P.D., R e y h e r K.K. (2016). Measuring the growth rate of UK dairy heifers to improve future productivity. Vet. J., 212: 9-14.

De Rens is F., S c aramuzzi R.F. (2003). Heat stress and seasonal effects on reproduction in the dairy cow - a review. Theriogenology, 60: 1139-1151.

DLG (2008). Heifer rearing - cornerstone for successful milk production. Studies of DLG. Vol. 203. DLG e.V., Frankfurt am Main, Germany.

Do C., Was an a N., Cho K., Choi Y., Choi T., Park B., Le e D. (2013). The effect of age at first calving and calving interval on productive life and lifetime profit in Korean Holsteins. AsianAustralas. J. Anim. Sci., 26: 1511-1517.

Froidmont E., Mayeres P., Picron P., Turlot A., Planchon V., Stilmant D. (2013). Association between age at first calving, year and season of first calving and milk production in Holstein cows. Animal, 7: 665-672.

He Z., S un Z., Lu i S., Z hang Q., Tan Z. (2009). Effects of early malnutrition on mental system, metabolic syndrome, immunity and the gastrointestinal tract. J. Vet. Med. Sci., 71: 1143-1150.

He in richs A.J., He in richs B.S. (2011). A prospective study of calf factors affecting first-lactation and lifetime milk production and age of cows when removed from the herd. J. Dairy Sci., 94: $336-341$.

Hornick J.L., Van Eenaeme C., Gérard O., Dufrasne I., Is tas se L. (2000). Mechanisms of reduced and compensatory growth. Domest. Anim. Endocrin., 19: 121-132.

$\mathrm{H} \mathrm{u}$ b e r K. (2018). Invited review: resource allocation mismatch as pathway to disproportionate growth in farm animals - prerequisite for a disturbed health. Animal, 12: 528-536.

Hultgren J., Svens s on C., Pehrss on M. (2011). Rearing conditions and lifetime milk revenues in Swedish dairy cows. J. Liv. Sci., 137: 108-115.

Krpálková L., Cabrera V.E., Vacek M., Štípková M., S tádník L., Crump P. (2014). Effect of prebubertal and postpubertal growth and age at first calving on production and reproduction traits during the first 3 lactations in Holstein dairy cattle. J. Dairy Sci., 97: 3017-3027.

Le Cozler Y., Lollivier V., Lac as se P., D is en ha s C. (2008). Rearing strategy and optimizing first-calving targets in dairy heifers: a review. Animal, 2: 1393-1404.

L e o n a rd N., K o c h C., R o m b e rg F.-J., R i e d e C., S t i e r C.-H. (2013). Das optimale Erstkalbealter - Praxisdaten aus Rheinland-Pfalz. (The optimal age at first calving - practical data from Rhineland-Palatinate). Accessed Jan. 24, 2017 http://www.dlr.rlp.de/internet/global/themen.nsf/74 7270cf8f15f0d1c1257abb0030380e/c929fa858d072aa4c1257b720041527a/\$FILE/Erstkalbealter Praxisdaten_RLP_2013.pdf

Maccari P., Wiedemann S., Kunz H.-J., Piechotta M., Sanftleben P., Kaske M. (2015). Effects of two different rearing protocols for Holstein bull calves in the first 3 weeks of life on health status, metabolism and subsequent performance. J. Anim. Physiol. Anim. Nutr., 99: $737-746$.

Mac don ald K.A., P e n n o J.W., B ry a n t A.M., R o c h e J.R. (2005). Effect of feeding level preand post puberty and body weight at first calving on growth, milk production, and fertility in grazing dairy cows. J. Dairy Sci., 88: 3363-3375.

Meyer M.J., Capuco A.V., Ross D.A., Lintault L.M., Van Amburg M.E. (2006 a). Developmental and nutritional regulation of the prepubertal heifer mammary gland: I. Parenchyma and fat pad mass and composition. J. Dairy Sci., 89: 4289-4297.

Meyer M.J., Capuco A.V., Ross D.A., Lintault L.M., Van Amburg M.E. (2006 b). Developmental and nutritional regulation of the prepubertal heifer mammary gland: II. Epithelia cell proliferation, parenchymal accretion rate, and allometric growth. J. Dairy Sci., 89: 4298-4304.

Mo a 11 e m U., Werner D., L e hrer H., Za chut M., Livshitz L., Yakoby S., Sha may A. (2010). Long-term effects of ad libitum whole milk prior to weaning and prepubertal protein supplementation on skeletal growth rate and first-lactation milk production. J. Dairy Sci., 93: 2639-2650.

M on te iro A.P.A., T a o S., Th o m p s on I.M.T., D a hl G.E. (2016). In utero heat stress decreases calf survival and performance through the first lactation. J. Dairy Sci., 99: 8443-8450.

Mourits M.C.M., Galligan D.T., D i jkhuizen A.A., Huirne R.B.M. (2000). Optimization of dairy heifer management decisions based on production conditions of Pennsylvania. J. Dairy Sci., 83: 1989-1997.

Müller U., Mlaouh A., Sharifi A.R., Staufenbiel R., Hasselmann L., Tripma- 
c h e r R., B r o c k m a n n G.A. (2007). The influence of energy content during the rearing period on physiological markers and milk yield: A study at monozygotic twins. Züchtungskunde, 79: 231-242.

Nardone A., Lacetera N., Bernabucci U., Ronchi B. (1997). Composition of colostrum from dairy heifers exposed to high air temperatures during late pregnancy and the early postpartum period. J. Dairy Sci., 80: 838-844.

R u th e r ford K. (2014). How stress during pregnancy affects the offspring. 7th Boehringer Ingelheim Expert Forum on Farm Animal Well-Being, June 13th 2014, Madrid (Spain), pp. 9-11.

Sejrsen K., Purup S., Vesterga ard M., Foldager J. (2000). High body weight gain and reduced mammary growth: physiological basis and implications for milk yield potential. Domest. Anim. Endocrinol., 19: 93-104.

Sham y A., Werner D., M o allem U., Barsh H., B ruckental I. (2005). Effect of nursing management on puberty, skeletal growth rate, and milk production during first lactation of dairy heifers. J. Dairy Sci., 88: 1460-1469.

S h e r w in V., Hu d s o n C., H e n d e r s o n A., B r e e n J. (2016). Measuring health and performance in preweaning dairy calves. In Practice, 38: 113-122.

Soberon F., Van Amburgh M.E. (2014). Lactation Biology Symposium: The effect of nutrient intake from milk or milk replacer of preweaned dairy calves on lactation milk yield as adults: A meta-analysis of current data. J. Anim. Sci., 91: 706-712.

Soberon F., Raffrenato E., Everett R.W., Van A mburgh M.E. (2012). Preweaning milk replacer intake and effects on long-term productivity of dairy calves. J. Dairy Sci., 95: 783-793.

S p i e kers H., P ot thas t V. (2004). Erfolgreiche Milchviehfütterung, DLG Verlag, Frankfurt a.M., Germany

S t o t t G.H. (1980). Immunoglobulin absorption in calf neonates with special considerations of stress. J. Dairy Sci., 63: 681-688.

Trilk J., Mün ch K. (2010). Connections between health of calves, growth and later milk yield of dairy cattle. Züchtungskunde, 80: 461-472.

Vac e k M., Krpálková L., S y růč e k J., Št í pková M., Ja n e cká M. (2015). Relationships between growth and body condition development during the rearing period and performance in the first three lactations in Holstein cows. Czech J. Anim. Sci., 60: 417-425.

VandeHaar M.J., Armentano L.E., Weigel K., Spurlock D.M., Tempelman R.J., Veerkamp R. (2016). Harnessing the genetics of the modern dairy cows to continue improvements in feed efficiency. J. Dairy Sci., 99: 4941-4954.

We s t J.W. (2003). Effects of heat-stress on production in dairy cattle. J. Dairy Sci., 86: 2131-2144.

Wi e d e m a n n S., Holz P., K un z H.-J., S t a m e r E., K a s k e M. (2015). Effect of ad libitum feeding of Holstein-Friesian calves during the first four weeks of life on weight development as well as milk yield and feed intake during first lactation. Züchtungskunde, 87: 413-422.

Zanton G.I., He in rich s A.J. (2005). Meta-analysis to assess effect of prepubertal average daily gain of Holstein heifers on first-lactation production. J. Dairy Sci., 88: 3860-3867.

Received: 27 II 2018

Accepted: 10 X 2018 